\title{
Tissue preference of some myxobolids (Myxozoa: Myxosporea) from the musculature of European freshwater fishes
}

\author{
Kálmán Molnár, Csaba Székely* \\ Institute for Veterinary Medical Research, Centre for Agricultural Research, Hungarian Academy of Sciences, PO Box 18 , \\ 1581 Budapest, Hungary
}

\begin{abstract}
For several species of fish myxosporeans known at present, the musculature has been designated as the location of intrapiscine development. In the majority of these cases, plasmodia and spores are actually found in the muscle cells, but there are also myxosporeans that select intermuscular connective tissue, fish bones, nerves and capillaries of the musculature as their site of development. During the plasmodial development of Myxobolus, Henneguya and Thelohanellus species in fish inhabiting Hungarian freshwaters, 3 main locations of development inside the muscles were identified. Pseudodispar-type plasmodia, such as M. cyprini, M. musculi and $M$. pseudodispar, form plasmodia intracellularly in the muscle cells, while the plasmodia of M. pfeifferi, M. sandrae and T. hovorkai develop in the intermuscular connective tissue. A similar development in the connective tissue of the ventricle and the bulbus arteriosus was observed for M. dogieli, a heart parasite found in some cyprinid fishes. The third type of development is represented by $M$. tauricus, which prefers the collagenous elements of the fin rays, but its plasmodia are commonly found in the muscle attached to the fish bones.
\end{abstract}

KEY WORDS: Myxosporea $\cdot$ Plasmodia $\cdot$ Site preference $\cdot$ Fish $\cdot$ Muscles

\section{INTRODUCTION}

Previous studies on the site selection of fish myxosporeans infecting the gills, fins and kidney (Molnár 1994, 2002a,b, 2007) suggested that different myxosporean species have a strict tissue tropism, and the site selection in the infected organ is rather characteristic of the given species. There are only scarce data about the site selection of myxosporeans in the muscle, and in many cases, only scattered spores found among muscle cells have been reported.

The muscle is a common site of establishment for various myxosporean species infecting fishes. In a synopsis of Myxobolus spp. of the world, Eiras et al. (2005) reported that $\sim 54$ of the 751 characterized species have been described from the muscles. In another synopsis on Henneguya spp. (Eiras 2002), 6 of the recorded 146 species were found to infect muscles, while from members of the Thelohanellus genus only a single species, $T$. hovorkai, is known to be a muscle parasite. The majority of muscle-dwelling species belong to the 'pseudodispar' type myxosporeans (M. cyprini Doflein, 1898, M. musculi Keysselitz, 1908, and M. pseudodispar Gorbunova, 1936). The plasmodia of these species develop intracellularly, and their mature plasmodia fill the large muscle cells. However, after rupture of the host cells, spores are carried to different organs of the fish body (Molnár \& Kovács-Gayer 1985, Baska 1987, Molnár et al. 2002). Myxosporeans showing histotropism to the connective or the cartilaginous tissues are also frequently found in muscles. Therefore, besides other locations, they infect connective tissue and cartilaginous tissue elements inside the musculature (Molnár \& Kovács- 
Gayer 1986, Molnár et al. 2002). Molnár (1994) suggested that myxosporeans are parasites having species, organ and tissue specificity, and this tissue specificity is of decisive importance as a given myxosporean species can develop only in a certain tissue. The importance of tissue specificity for gill-infecting Myxobolus spp. has been supported by molecular studies as well (Eszterbauer 2004).

Muscle is the main constituent of the fish body. In addition to muscle cells, the musculature contains blood vessels, nerves and connective tissue as well as cartilaginous and bony elements (Harder 1975, Ferguson 1989). Muscle fibres originate and end on broad sheets of connective tissue, the myosepta (Fig. 1). The space between muscle fibres is also filled by loose connective tissue. In several fish, myosepta are supported by bony elements formed by a collagenous dense connective tissue, which has been calcified in some fish. Therefore, due to their different tissue affinities, myxosporeans can occur in diverse locations within the musculature and might affect muscle cells, connective tissue, bones, nerves and blood vessels.

The aim of the present paper is to call attention of authors to the importance of tissue and site specificity

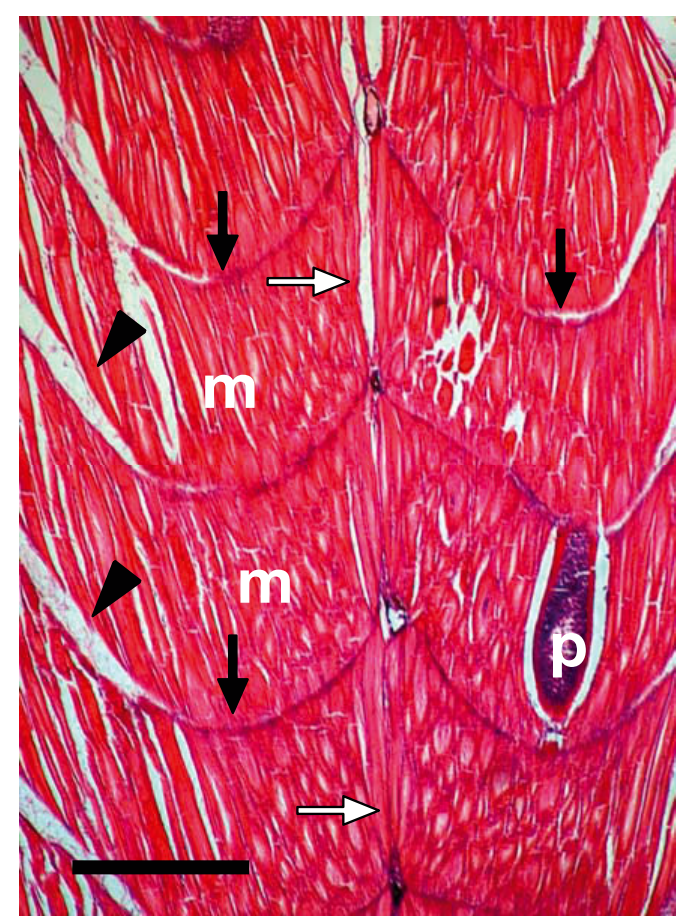

Fig. 1. Scardinius erythrophthalmus muscle structure. Muscle cells (m) start and end between transversal myosepta (arrows); longitudinal myoseptum (white arrows); fish bones (arrowheads); intramuscular plasmodium of Myxobolus pseudodispar (p). H\&E staining. Scale bar $=400 \mu \mathrm{m}$ and to describe the most characteristic development and tissue affinities of myxosporean plasmodia in the musculature, based on studies performed on Мухоbolus, Henneguya and Thelohanellus spp.

\section{MATERIALS AND METHODS}

Records involving infections of the muscle with myxosporean parasites throughout a 25 yr period were evaluated, and the site selection of different species was typified. During that period, several hundred fish were dissected and examined for parasitic infections. In the majority of cases, a complete parasitological dissection was made, and histological sections were prepared. Myxosporean parasites were identified based on their morphology, and DNA studies were also performed on some of the species studied by us. Preparations were selected from the authors' histological collections. This collection served as a resource for examining the site selection of myxosporeans in the gills, fins and kidneys (Molnár 1994, 2002a,b, 2007). Histological sections were made from pieces of muscle from various fish species infected with different developmental stages of Myxobolus, Henneguya and Thelohanellus spp. Uninfected fish hatched and cultured in laboratory were also examined as controls. Samples were collected from 10 fish species: common carp Cyprinus carpio, barbel Barbus barbus, common bream Abramis brama, white bream Blicca bjoerkna, roach Rutilus rutilus, rudd Scardinius erythrophthalmus, chub Squalius cephalus, bleak Alburnus alburnus, pike Esox lucius and pike-perch Sander lucioperca. For microscopy, 0.5 to $1 \mathrm{~cm}^{3}$ pieces of muscle were excised from different parts of the trunk musculature and fixed in Bouin's solution for 4 and $12 \mathrm{~h}$ in the case of small and large pieces, respectively. The muscle pieces were washed in $80 \%$ ethanol several times and embedded in paraffin wax. Thin sections (4 to $8 \mu \mathrm{m}$ ) were stained with haematoxylin and eosin (H\&E) and Farkas-Mallory's technique (Kiszely \& Barka 1958). Microscopic photos were prepared with the help of video equipment attached to an Olympus BH-2 microscope, to obtain digitised pictures (Székely 1997) and with a type DP10 and DP-20 Olympus digital camera.

\section{RESULTS}

Myxosporean infection was found in the muscle tissue of all the fish species studied, with the exception of pike Esox lucius. In the majority of cases, plasmo 
dia were found intracellularly in muscle cells. In early infections, the spindle-shaped developing plasmodium was located in the centre of the cross-sectioned cell, surrounded by the rest of the cytoplasm (Fig. 2). In more progressed cases, the infected cells were completely filled by sporogonic stages and spores, and the cytoplasm of the infected cells could usually not be observed (Fig. 3). In all cases of intracellular infections, 'pseudodispar type' spores having a deformed ellipsoidal shape and unequal polar capsules were isolated from the cysts. Spores from roach Rutilus rutilus, rudd Scardinius erythrophthalmus, bream Abramis brama, white bream Blicca bjoerkna, chub Squalius cephalus and bleak Alburnus alburnus were identified as Myxobolus pseudodispar, while those from common carp Cyprinus carpio and barbel Barbus barbus were identified as M. cyprini and M. musculi, respectively. In more progressed infections of these fish, masses of spores released from disintegrated muscle cells were found between the intact muscle cells (Fig. 4). The same fish had scattered spores in different organs, particularly in the kidney (Fig. 5), accumulated in melano-macrophage centres. Very often, a portion of the spores released from destroyed muscle cells remained in place and were surrounded by a connective tissue capsule (Fig. 6).

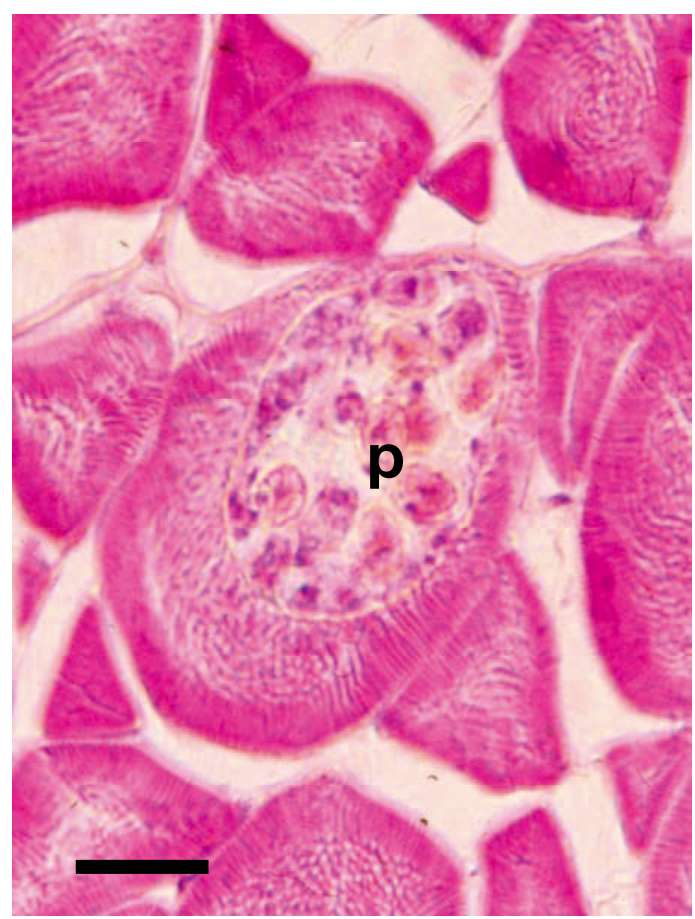

Fig. 2. Developing intracellular plasmodium (p) of Myxobolus cyprini in a cross-sectioned muscle cell of common carp Cyprinus carpio. The plasmodium is filled by sporogonic stages and young spores. H\&E. Scale bar $=20 \mu \mathrm{m}$

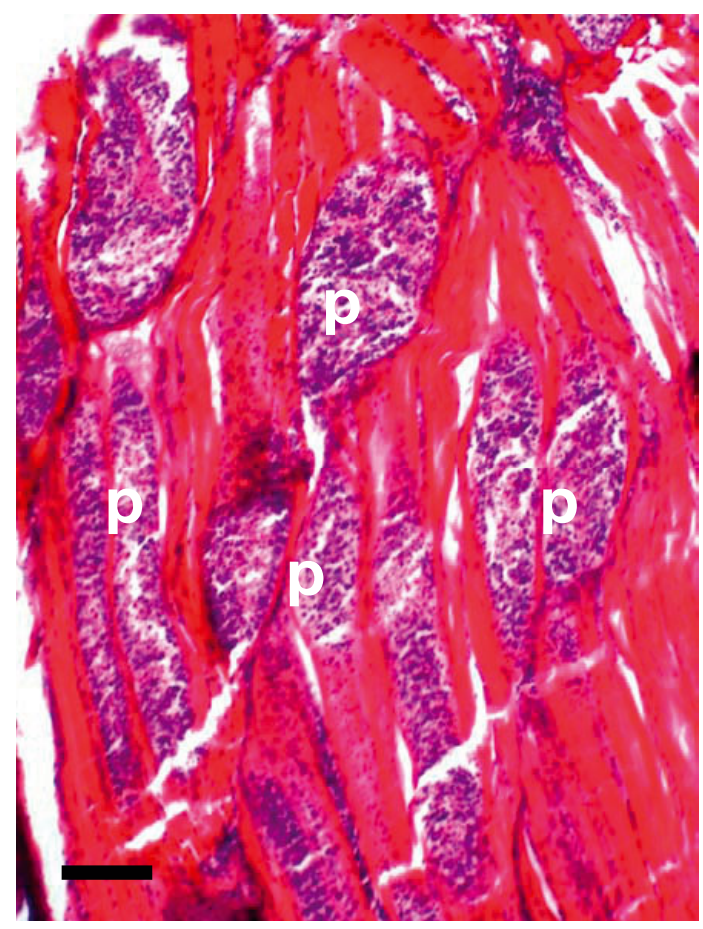

Fig. 3. Longitudinal section of the muscle of rudd Scardinius erythrophthalmus. Muscle cells are infected with elongated mature plasmodia (p) of Myxobolus pseudodispar. H\&E. Scale bar $=200 \mu \mathrm{m}$

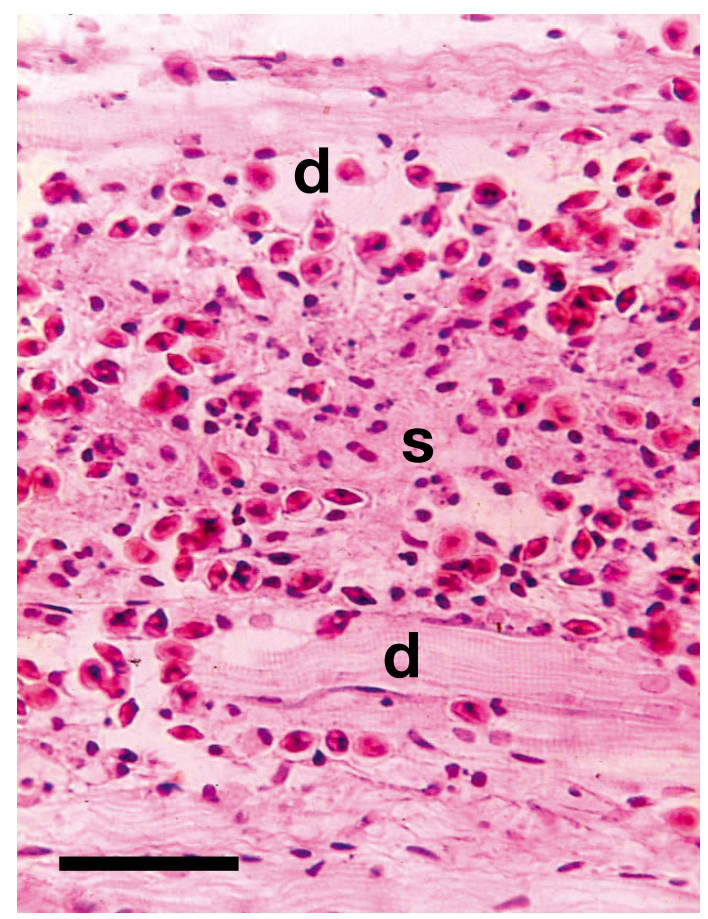

Fig. 4. A mass of Myxobolus cyprini spores in the intermuscular space, released from a disrupted plasmodium of the damaged host cell. Remnants of degenerated muscle cells (d) are seen in the spore mass (s). H\&E. Scale bar $=40 \mu \mathrm{m}$ 


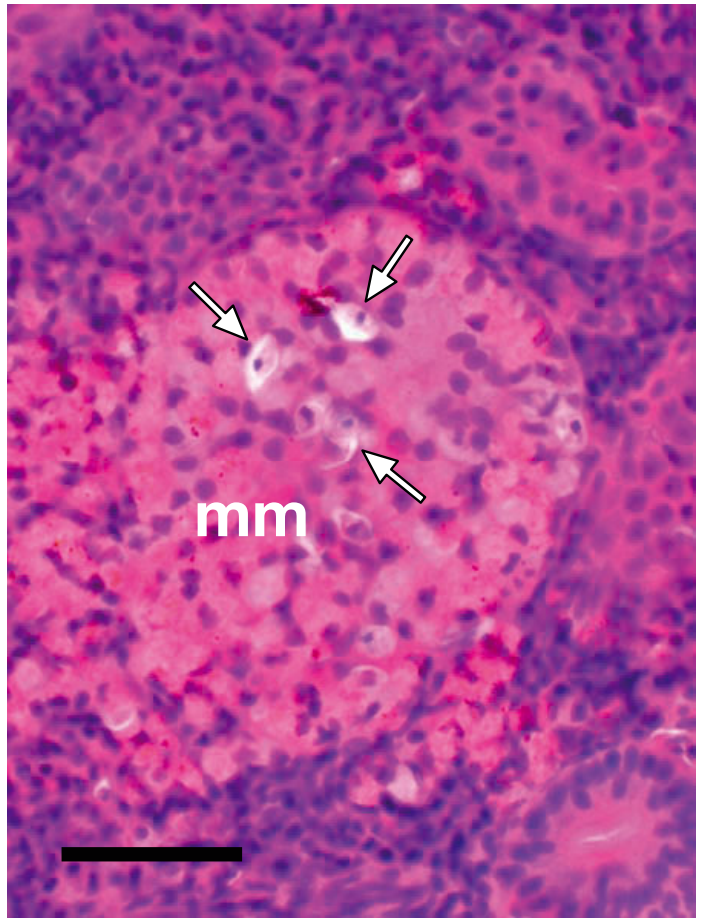

Fig. 5. Scattered spores of Myxobolus cyprini (arrows) in a melano-macrophage centre $(\mathrm{mm})$ of the kidney of common carp Cyprinus carpio. White arrows show damaged $M$. cyprini spores. H\&E. Scale bar $=40 \mu \mathrm{m}$

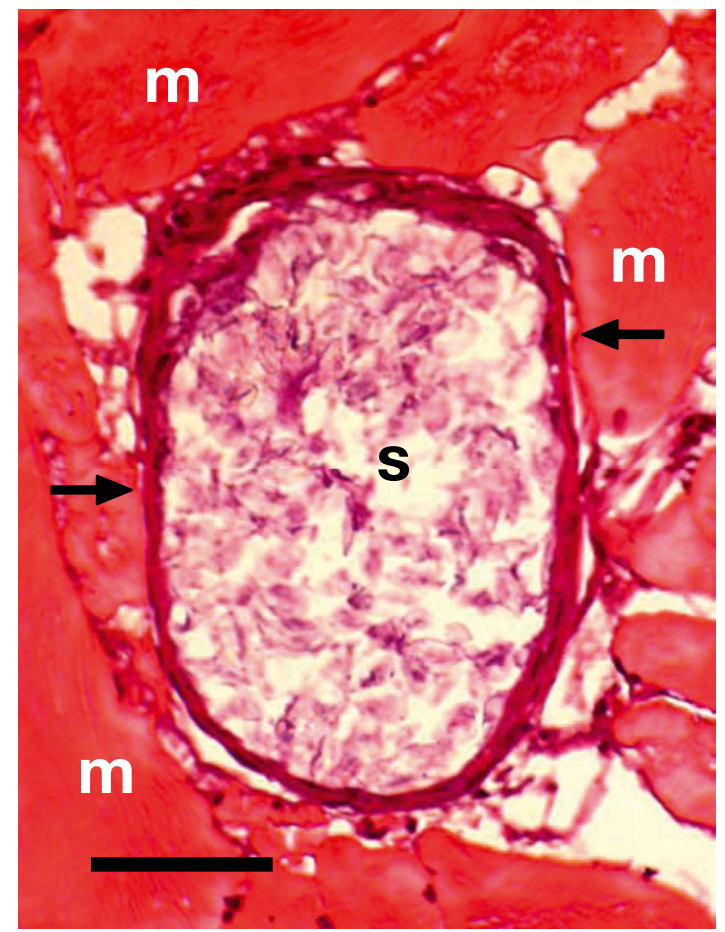

Fig. 6. Myxobolus pseudodispar spores (s) among crosssectioned muscle cells (m) of roach Rutilus rutilus, encapsulated by a thick connective tissue layer (arrows). H\&E. Scale bar $=40 \mu \mathrm{m}$
This might erroneously suggest a connective tissue tropism.

Infection of the intermuscular connective tissue was observed in the case of Myxobolus sandrae in the pike-perch Sander lucioperca. The presence of $M$. sandrae was only rarely recorded, but it always caused a heavy infection in the musculature. This parasite had a strict affinity to connective tissues. Plasmodia of $M$. sandrae were located inside the wide myosepta (Fig. 7), which substitute for the muscle bones in this fish. Plasmodia developing in the intermuscular connective tissue were also found in Thelohanellus hovorkai Akhmerov, 1955 infection of the common carp (Fig. 8), but in these cases, plasmodia of the same species were also found in the periocular space and on the gut serosa. A similar infection in the intermuscular connective tissue was recorded by Molnár et al. (2012) for M. pfeifferi Thélohan, 1895, the most common intermuscular species in Iberian barbel. A special case of infection of the intermuscular connective tissue was observed in a M. dogieli Bykhovski \& Bykhovskaya, 1940 infection in the common bream Abramis brama. Infestation with mature plasmodia affected mostly the bulbus arteriosus (Fig. 9), but sporadic plasmodia were also found in the ventricle of the heart. In both the bulbus and the ventricle, plasmodia developed

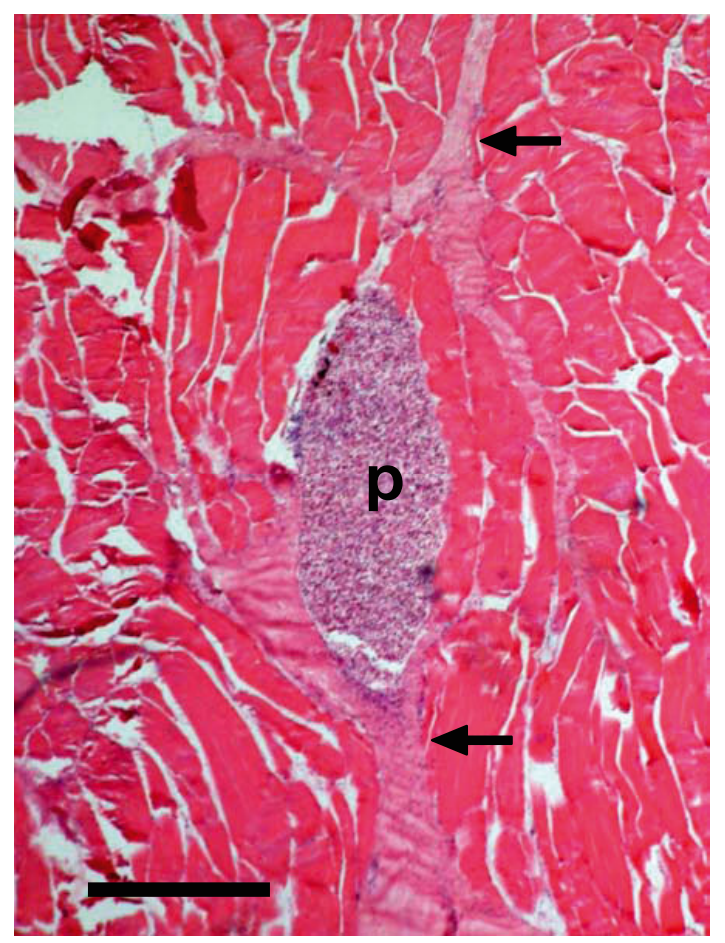

Fig. 7. A Myxobolus sandrae plasmodium (p) located in the intermuscular septa (arrows) of the muscle of pike-perch Sander lucioperca. H\&E. Scale bar $=200 \mu \mathrm{m}$ 


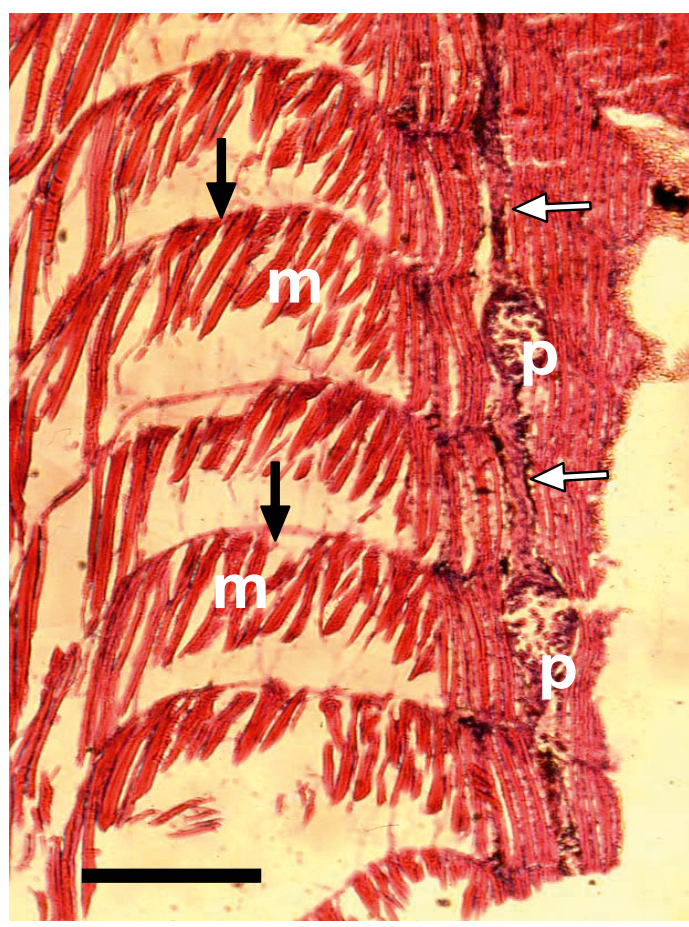

Fig. 8. Thelohanellus hovorkai plasmodia (p) in a longitudinally running intermuscular septum (white arrows) of common carp Cyprinus carpio. Transversal septa (black arrows) between muscle bundles (m). H\&E. Scale bar $=400 \mu \mathrm{m}$

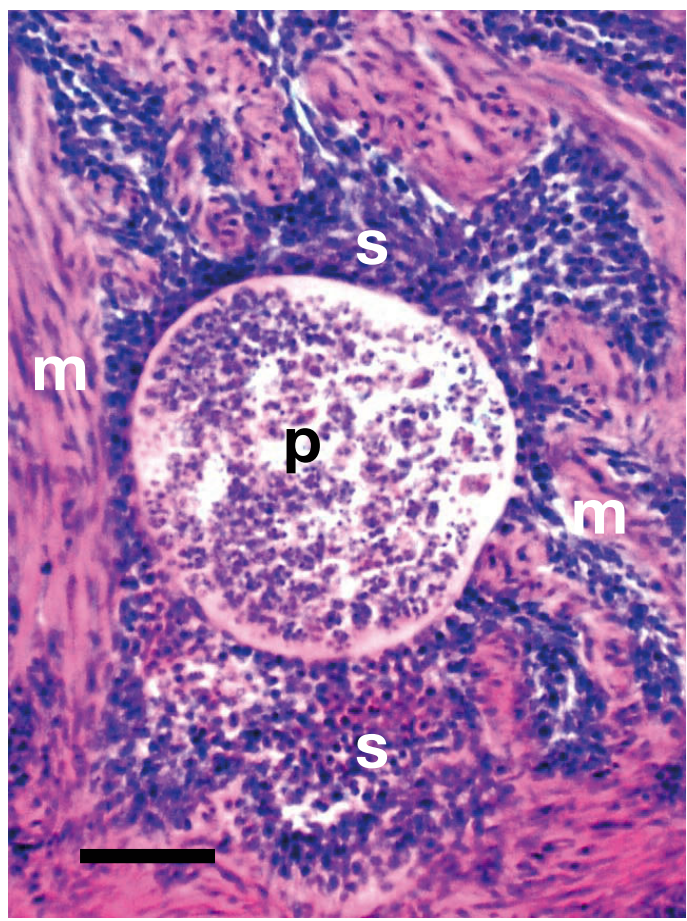

Fig. 9. Myxobolus s. 1. dogieli plasmodium (p) surrounded by cells of the subendocardium (s) in the wall of the bulbus arteriosus composed of smooth muscle cells (m). H\&E. Scale bar $=50 \mu \mathrm{m}$ exclusively in the connective tissue and were never found inside the muscle cells.

A third type of location for myxosporean plasmodia in the muscle was observed in infection of the barbel Barbus barbus with Myxobolus tauricus Miroshnichenko, 1979. This collagenophilic species was commonly found to infect the fins, but its cysts also frequently occurred in the musculature associated with the fish bones. Plasmodia of this species in the muscle were always located in the collagenous dense connective tissue covering the muscle bones (Fig. 10).

Myxosporean infection is common also in the heart, from which tissue some known Myxobolus species, such as $M$. cordis and M. paralintoni have been isolated. However, no data are known regarding whether muscle cells of the heart tissues are infected. Molnár et al. (2008), who studied M. dogieli infection of the common bream Abramis brama, found plasmodia only in the intermuscular connective tissue.

\section{DISCUSSION}

Previous syntheses (Molnar 2002a,b, 2007) have demonstrated the importance of site selection as a diagnostic characteristic for myxosporean species in-

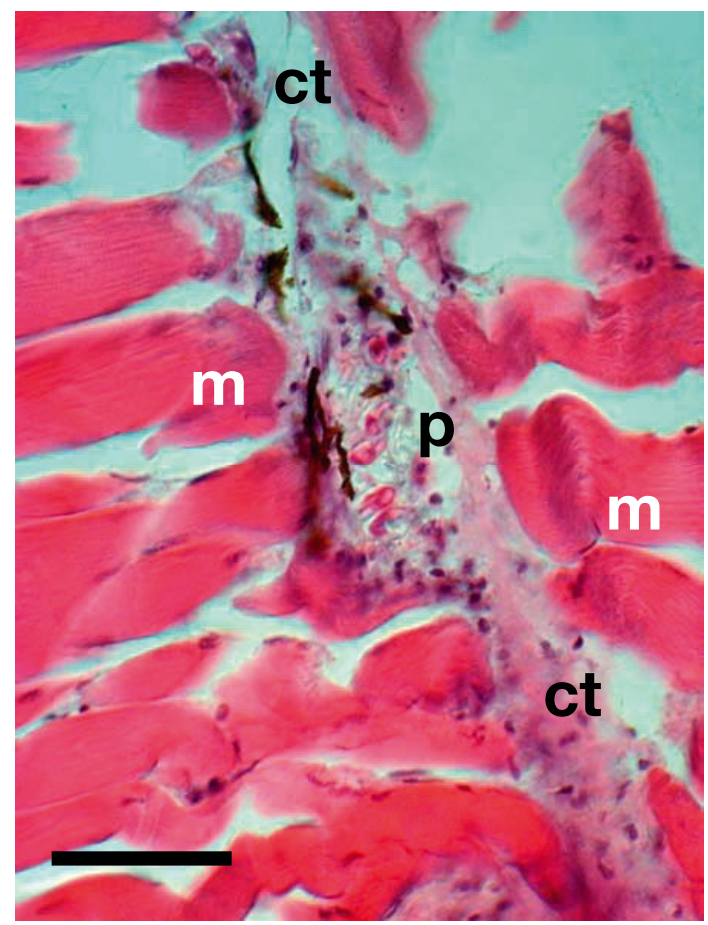

Fig. 10. A mature Myxobolus tauricus plasmodium (p) with spores in the collagenous connective tissue (ct) covering fish bones. Muscle bundles (m) start and end at the bones. H\&E. Scale bar $=40 \mu \mathrm{m}$ 
fecting gills, fins and kidneys. Here we discuss site selection in musculature and describe different site preferences in that tissue. The musculature of fish is a complex organ composed of connective tissue, cartilage, bones, nerves and blood vessels in addition to muscle cells. Therefore, parasites infecting the musculature might also develop in some of these other cell and tissue types rather than only in muscle cells. In freshwater fishes, Myxobolus spp. seem to occur commonly in the musculature, but compared to infections of other organs, their occurrence in muscles is relatively low. Data on muscle-dwelling Myxobolus spp. pertain mostly to the skeletal muscles, but Myxobolus infection in the heart and smooth muscle of the intestine is also known. The number of documented muscle infections caused by developing or mature plasmodia is relatively low, as most authors reported only the occurrence of solitary spores in the musculature. The number of undiscovered muscle infections might be significantly higher, as recently several papers have been published on Myxobolus spp. infecting the muscles. The majority of these papers describe species developing intracellularly in striated muscle cells. In Europe, $M$. cyprini is the best known representative of this parasite group, but M. musculi and M. pseudodispar are also well studied (Molnár \& Kovács-Gayer 1985, Baska 1987, Székely et al. 2001, Molnár et al. 2002). Several Myxobolus spp. (M. wellerae Li \& Desser, 1985, M. burti Cone \& Marcogliese, 2010, M. ridouti Easy \& Cone, 2009, M. ridgwayi Easy \& Cone, 2009) are mentioned from North American cyprinids (Li \& Desser 1985, Easy \& Cone 2009, Cone \& Marcogliese 2010), but similar intracellular infections caused by M. procerus Cone et al., 2005 and M. intramusculi Cone et al., 2005 have also been recorded in the percid Percopsis omiscomaycus (Cone et al. 1997, Easy et al. 2005) as well as an infection by $M$. insidiosus Wyatt \& Pratt, 1963 in the salmonid Oncorhynchus tshawytscha (Wyatt \& Pratt 1963, Ferguson et al. 2008). In Asia, M. lentisuturalis Dyková et al., 2002, a pathogenic species infecting the gibel carp in China, is the best-studied species developing intracellularly in muscle (Dyková et al. 2002, Caffara et al. 2009), but some Malaysian species, such as $M$. omari Székely et al., 2009, M. leptobarbi Székely et al., 2009, M. tasikkenyirensis Székely et al., 2009 also seem to be typical muscle parasites (Székely et al. $2009 a, b)$. On the Indian subcontinent, 7 out of the 97 Myxobolus species listed by Kalavati \& Nandi (2007) have been located in muscle. These are $M$. bhadrensis Seenappa \& Manohar, 1981, M. hosadurgensis Seenappa \& Manohar, 1981, M. indicum Tripathi,
1952, M. karnatakae Hagargi \& Amoji, 1981, M. variformis (Haldar et al., 1996) Kalavati \& Nandi, 2007, M. etropli Rajendran et al., 1992, and M. ophthalmusculata Basu \& Haldar, 2002. In the absence of histological data, only the first 5 of the species mentioned above seem to be intracellularly developing species of the skeletal muscle; $M$. etropli infects the heart and bulbus arteriosus, and M. ophthalmusculata seems to have a more pronounced connective tissue tropism, as it is also found in different nonmuscular parts of the fish body in addition to infecting the eye muscles.

The relatively low number of documented muscle infections might be attributed to the technical difficulties of examining muscles. Diagnosing a myxosporean infection in the muscle is rather difficult. While even small plasmodia can readily be detected in the gills, plasmodia infecting the muscles must be studied in well-compressed muscle samples, and in most cases, the use of a compound microscope is necessary. Alternatively, the occurrence of solitary spores in different organs, especially in macrophage centres, might call attention to infection of the muscle. In myxosporean infections of the musculature, many of the relatively large muscle cells are infected, and large numbers of spores are produced. Spores released from the necrotic host cells can leave the body of a living host only via the blood stream, which carries the spores to different organs. In the case of Myxobolus cyprini infection, Molnár \& Kovács-Gayer (1985) found that spores transported to the gills, skin, gut and kidney were regarded as foreign bodies by melano-macrophage centers, which promoted their expulsion from the fish body.

Only a single paper (Maghami et al. 2008) provided evidence that Myxobolus infection can develop in the smooth muscle of the intestine. In contrast, several papers mention infection of the heart (Bykhovskaya-Pavlovskaya \& Bykhovski 1940, Heckmann \& Jensen 1978, Bauer et al. 1991, Masoumian et al. 1996a, Cone \& Overstreet 1998). Histological data on infection of the heart and bulbus arteriosus were first presented by Heckmann \& Jensen (1978), who found Henneguya sebasta Moser \& Love, 1992 infection in the heart of the Pacific rockfish and stated that plasmodia developed in the tunica adventitia and tunica interna layers of the truncus and bulbus arteriosus. From the same organs of Barbus sharpeyi, Masoumian et al. (1996b) described M. bulbocordis Masoumian et al. 1996, which caused heavy infections, but its plasmodia showed affinity to connective tissue cells and were not associated with muscle cells. A similar infection caused 
by M. jillimorei Cone \& Overstreet, 1998 and M. paralintoni Li \& Desser, 1985 was found in the bulbus arteriosus of centrarchid fish by Cone \& Overstreet (1998). Both species developed in the non-muscular epicardium of the bulbus. In the Chinese sea bass Lateolabrax sp., Yokoyama et al. (2003) reported cardiac henneguyosis caused by $H$. lateobracis. The plasmodia of the above species were located in the adventitial and medial layers of the bulbus. In another work, Yokoyama et al. (2005) described $H$. pagri Yokoyama et al., 2005 infection in the bulbus arteriosus of the red sea bream Pagrus major (Temminck \& Schlegel, 1843). In addition to causing degenerative cardiomyopathy, this infection produced degenerative changes in the gills through its disseminated spores. In a further study on this subject, Molnár et al. (2008) described M. dogieli infection in the heart and bulbus of common bream Abramis brama. Although according to Icardo et al. (2002) the middle layer of the bulbus arteriosus of fish contains smooth muscle cell elements, Molnár et al. (2008) stated that the plasmodia of $M$. dogieli infected only the connective tissue of the heart and the bulbus arteriosus. From data presented by some authors (Heckmann \& Jensen 1978, Masoumian et al. 1996b, Yokoyama et al. 2005, Molnár et al. 2008), it appears that muscle cells are only indirectly damaged, and no myxosporean development takes place in the muscle tissue of the heart.

In addition to infection of the heart, there are also infections in the skeletal muscle, where spores and plasmodia are found in the musculature but muscle cells are not infected. In these cases, the intermuscular connective tissue is the site of infection for some well-known species. Myxobolus pfeifferi, the causative agent of boil disease of common barbell Barbus barbus, forms large plasmodia in the intermuscular connective tissue, deforming and damaging muscle cells only in an indirect way. A similar intramuscular location is seen in $M$. sandrae infection of the pikeperch Sander lucioperca. This infection is characterized by formation of large plasmodia in the thick intermuscular septa. Thelohanellus hovorkai, a pathogenic species of common carp, is a typical connective tissue parasite. It usually forms plasmodia in the abdominal cavity, attached to the gut and in the eye bulb. Its plasmodia, however, are commonly found in the intermuscular connective tissue as well.

In our study of myxosporean infections, most of these infections occurred in the muscle cells and intermuscular connective tissue of fish. In a single case of Myxobolus tauricus infection, however, a new type of infection was recorded when plasmodia inside the muscle developed on the fish bones. If we regard $M$. tauricus as a collagenophilic species developing in the collagenous tissues, its appearance in the muscle is not a surprise. Fish bones are formed by calcification of collagenous elements of the dense connective tissue in a manner similar to the formation of the scales.

Infection of the nerves by myxosporean parasites is less common. However, Ferguson et al. (2008) reported that Myxobolus fryeri, a species described by those authors, formed plasmodia in the intermuscular nerve bundles, and El-Matbouli et al. (1995) proved that $M$. cerebralis also uses the nerves as a corridor to cartilage. In the cases studied in the present work, infection of the nerves did not occur; however, it is well understood that the muscles interwoven with nerves might be infected by some myxosporeans. We lack data on the role of capillaries in the early development of Myxobolus plasmodia; however, based on observations made in gill infections, it is likely that some infections occurring at intermuscular sites actually start in the blood vessels.

Acknowledgements. The present study was supported by the Hungarian Scientific Research Fund (OTKA, project no. $\mathrm{K}$ 100132) and by the Grant of the Hungarian Government, managed by the National Development Agency, and financed by the Research and Technology Innovation Fund (KTIA AIK-12-1-2013-0017). The authors thank G. Ostoros for making the histological slides and labelling the pictures. The authors also thank D. Dunams-Morel for reviewing the paper and for her suggestions.

\section{LITERATURE CITED}

Baska F (1987) Histological studies on the development of Myxobolus pseudodispar Gorbunova, 1936 in the roach (Rutilus rutilus). Acta Vet Hung 35:251-257

Bauer ON, Voronin VN, Yunchis ON (1991) Infection of the heart in carp caused by Myxobolus dogieli (Myxosporea, Myxobolidae). Angew Parasitol 32:42-44

Bykhovskaya-Pavlovskaya IE, Bykhovski BE (1940) Parasite fauna of fishes of Akhtarinsk Bays (Azov Sea, River Kuban Delta). Parazitol Sb 8:131-161 (in Russian)

Caffara M, Raimondi E, Florio D, Marcer F, Quaglio F, Fioravanti ML (2009) The life cycle of Myxobolus lentisuturalis (Myxozoa: Myxobolidae), from goldfish (Carassius auratus auratus), involves a Raabeia-type actinospore. Folia Parasitol 56:6-12

Cone DK, Marcogliese DJ (2010) Description of a new species of myxozoan from Notropis hudsonius in the Great Lakes region of Canada. J Parasitol 96:1164-1167

> Cone DK, Overstreet RM (1998) Species of Myxobolus (Myxozoa) from the bulbus arteriosus of centrarchid fishes in North America, with description of two new species. J Parasitol 84:371-374

Cone DK, Eurell T, Axler L, Rau D, Beasley V (1997) Intense infections with a variant of Myxobolus procerus (Myxo- 
sporea) in muscle of trout-perch (Percopsis omiscomaycus) in Duluth Harbor, Lake Superior. Folia Parasitol 44: $7-11$

> Dyková I, Fiala I, Nie P (2002) Myxobolus lentisuturalis sp. n. (Myxozoa: Myxobolidae), a new muscle-infecting species from the Prussian carp, Carassius gibelio from China. Folia Parasitol 49:253-258

Easy R, Cone D (2009) Taxonomy of Myxobolus ridouti n. sp. and M. ridgwayi n. sp. (Myxozoa) from Pimephales notatus and Semotilus atromaculatus (Cypriniformes) in Ontario. J Parasitol 95:1446-1450

Easy RH, Johnson SC, Cone DK (2005) Morphological and molecular comparison of Myxobolus procerus and M. intramusculi n. sp. (Myxozoa) parasitising muscles of the trout-perch (Percopsis omiscomaycus). Syst Parasitol 61:115-122

Eiras JC (2002) Synopsis of the species of the genus Henneguya Thelohan, 1892 (Myxozoa: Myxosporea: Myxobolidae). Syst Parasitol 52:43-54

- Eiras JC, Molnár K, Lu YS (2005) Synopsis of the genus Myxobolus Bütschli, 1882 (Myxozoa: Myxosporea: Myxobolidae). Syst Parasitol 61:1-46

El-Matbouli M, Hoffmann RW, Mandok C (1995) Light and electron microscopic observations on the route of triactinomyxon-sporoplasm of Myxobolus cerebralis from epidermis to rainbow trout cartilage. J Fish Biol 46:919-935

> Eszterbauer E (2004) Genetic relationship among gillinfecting Myxobolus species (Myxosporea) of cyprinids: molecular evidence of importance of tissue-specificity. Dis Aquat Org 58:35-40

Ferguson HW (1989) Systemic pathology of fish. Iowa State University Press, Ames, IA

- Ferguson JA, Atkinson SD, Whipps CM, Kent ML (2008) Molecular and morphological analysis of Myxobolus spp. of salmonid fishes with the description of a new Myxobolus species. J Parasitol 94:1322-1334

Kiszely Gy, Barka T (1958) Practical microtechnic and histochemistry. Kossuth, Budapest (in Hungarian)

Harder W (1975) Anatomy of fishes. Parts I and II. E. Schweizerbart'sche Verlagsbuchhandlung (Nägele u. Obermiller), Stuttgart

> Heckmann RA, Jensen LA (1978) The histopathology and prevalence of Henneguya sebasta and Kudoa clupeidae in the rockfish Sebastes paucispinis of Southern California. J Wildl Dis 14:259-262

- Icardo JM, Colvee E, Cerra MC, Tota B (2002) The structure of the conus arteriosus of the sturgeon (Acipenser naccarii) heart: II. The myocardium, the subendocardium. Anat Rec 267:17-27

Kalavati C, Nandi NC (2007) Myxosporean parasites of Indian fishes. Zoological Survey of India, Kolkata

Li L, Desser SS (1985) The protozoan parasites of fish from two lakes in Algonquin Park, Ontario. Can J Zool 63: 1846-1858

Maghami SSG, Jafari BJ, Masoumian M (2008) Myxobolus nodulointestinalis intestinal parasite of Barbus fishes in Khozestan, Iran. J Anim Vet Adv 7:231-234

Masoumian M, Baska F, Molnár K (1996a) Myxobolus nodulointestinalis sp. n. (Myxosporea, Myxobolidae), a parasite of the intestine of Barbus sharpeyi. Dis Aquat Org 24: 35-39

Editorial responsibility: Dieter Steinhagen,

Hannover, Germany
Masoumian M, Baska F, Molnár K (1996b) Description of Myxobolus bulbocordis sp. nov. (Myxosporea: Myxobolidae) from the heart of Barbus sharpeyi (Günther) and histopathological changes produced by the parasite. J Fish Dis 19:15-21

Molnár K (1994) Comments on the host, organ and tissue specificity of fish myxosporeans and on the types of their intrapiscine development. Parasitol Hung 27:5-20

Molnár K (2002a) Site preference of myxosporeans in the gill. Dis Aquat Org 48:197-207

Molnár K (2002b) Site preference of myxosporean spp. on the fins of some Hungarian fish species. Dis Aquat Org 52:123-128

Molnár K (2007) Site preference of myxozoans in the kidneys of Hungarian fishes. Dis Aquat Org 78:45-53

Molnár K, Kovács-Gayer E (1985) The pathogenicity and development within the host fish of Myxobolus cyprini Doflein, 1898. Parasitology 90:549-555

Molnár K, Kovács-Gayer E (1986) Biology and histopathology of Thelohanellus hovorkai Achmerov, 1960 (Myxosporea, Myxozoa), a parasite of the common carp (Cyprinus carpio). Acta Vet Hung 34:67-72

Molnár K, Eszterbauer E, Székely C, Dán Á, Harrach B (2002) Morphological and molecular biological studies on intramuscular Myxobolus spp. of cyprinid fish. J Fish Dis 25:643-652

Molnár K, Cech G, Székely C (2008) Infection of the heart of the common bream, Abramis brama (L.), with Myxobolus s. l. dogieli (Myxozoa, Myxobolidae). J Fish Dis 31: 613-620

Molnár K, Eszterbauer E, Marton S, Székely C, Eiras JC (2012) Comparison of the Myxobolus fauna of common barbel from Hungary and Iberian barbel from Portugal. Dis Aquat Org 100:231-248

Székely Cs (1997) Possible applications of video technology and digital image processing in fish parasitology: morphological examination of the groups Apicomplexa and Myxosporea-Actinosporea by video technology. Bull Eur Assoc Fish Pathol 17:81-82

Székely Cs, Molnár K, Rácz O (2001) Complete developmental cycle of Myxobolus pseudodispar (Myxosporea: Myxobolidae). J Fish Dis 24:461-468

Székely Cs, Shaharom-Harrison F, Cech G, Ostoros G, Molnár K (2009a) Myxozoan infections in fishes of the Tasik Kenyir Water Reservoir, Terengganu, Malaysia. Dis Aquat Org 83:37-48

Székely Cs, Shaharom-Harrison F, Cech G, Mohamed K, Molnár K (2009b) Myxozoan pathogens of Malaysian fishes cultured in ponds and net-cages. Dis Aquat Org 83:49-57

> Wyatt EJ, Pratt I (1963) Myxobolus insidiosus sp. n., a myxosporidian from musculature of Oncorhynchus tshawytscha (Walbaum). J Parasitol 49:951-955

Yokoyama H, Kawakami H, Yasuda H (2003) Henneguya lateolabracis sp. n. (Myxozoa: Myxosporea), the causative agent of cardiac henneguyosis in Chinese sea bass Lateolabrax sp. Fish Sci 69:1116-1120

Yokoyama H, Itoh N, Tanaka S (2005) Henneguya pagri n. sp. (Myxozoa: Myxosporea) causing cardiac henneguyosis in red sea bream, Pagrus major (Temminck \& Schlegel). J Fish Dis 28:479-487

Submitted: March 1, 2013; Accepted: October 21, 2013 Proofs received from author(s): December 20, 2013 